\section{Consumo frequente de bebidas alcoólicas por adolescentes escolares: estudo de fatores associados}

\section{Frequent consumption of alcohol by school age adolescents: study of associated factors}

Analy Marquardt de Matos

Rosely Cabral de Carvalho

Maria Conceição Oliveira Costa

Karina Emanuella Peixoto de Souza Gomes

\section{Luciana Maia Santos}

Departamento de Saúde da Universidade Estadual de Feira de Santana - UEFS; Núcleo de Estudos e Pesquisas na Infância e Adolescência - NNEPA/UEFS;

Programa de Pós-Graduação em Saúde Coletiva - PPGSC.

\section{Resumo}

Objetivo: Analisar fatores associados ao consumo freqüente/pesado de bebidas alcoólicas por adolescentes em Feira de Santana, Bahia. Método: estudo transversal, com amostra aleatória, estratificada por conglomerado, totalizando 10 escolas de portes diferenciados, com uma amostra de 1409 alunos, sendo nesse estudo foram incluídos 776 estudantes com o padrão de consumo estudado, de ambos os sexos, na faixa etária 14 a 19 anos, assegurando representatividade das escolas e alunos. $\mathrm{O}$ instrumento auto-aplicável foi elaborado segundo OMS e questionários validados em outros estudos. A coleta garantiu procedimentos para anonimato e sigilo. Foram considerados expostos, adolescentes que referiram consumo freqüente/pesado de bebidas alcoólicas (todo final de semana). Resultados: O consumo freqüente/ pesado mostrou associações significantes com sexo masculino, consumo precoce, parceiro sexual pouco conhecido, problemas com SPAs na família, coabitação com companheiro, renda própria, tráfico de drogas, consumo com amigos, atividades na escola, motivações (ansiedade, animação/prazer); e conseqüências (outras SPAs, brigas, inadimplência ao trabalholescola). Conclusões: o conhecimento dos fatores pessoais, interpessoais, familiares e ambientais associados ao consumo de bebidas alcoólicas por adolescentes devem ser considerados na implementação de programas escolares e políticas públicas de prevenção, visando comportamentos que minimizem a exposição ao risco associado.

Palavras-chave: adolescência, consumo de bebidas alcoólicas, fatores associados. 


\section{Abstract}

Objectives: To analyze heavy / frequent/ of alcohol use and to identify factors associated among adolescents in Feira de Santana, Bahia. Methods: Cross-sectional study with random samples, stratified by conglomerates, totaling 10 schools of different sizes. Although 1,409 students were included in the sample, only 776 of both genders, aged 14 to 19 years who reported alcohol use were included in the analysis,, ensuring representativeness of schools and students. The data collection instruments were a self-administered questionnaire developed according to OMS recommendations and other validated instruments from similar studies. Anonymous confidential data collection was assured. There were considered exposed adolescents who reported heavy/ frequent alcohol use (at least every weekend). Results: The frequent / large alcohol use was associated with male gender; early initiation of alcohol use; little-known sexual partner; problems with other drugs in the family; living with a partner (RP 4.73, CI 1.69-13.27); own income; drug trafficking; consumption with friends, activities at school, motivations (anxiety, excitement/pleasure) and consequences (other PDs, fights, bad debts to work/school) Conclusions: Knowledge of personal, interpersonal, family and environmental factors associated with alcohol use in adolescents should be considered in the implementation of school programs and public policies for alcohol use prevention focusing on behaviors that could minimize exposure to risk.

KEY WORDS: adolescence, consumption of alcohol, associated factors.

\section{Introduction}

The production and use of psychoactive drugs (PDs) including alcohol have been described in social situations in different historical times. The advent of the industrial revolution and increased production and marketing of PDs have brought about a significant growth in their use.

It is estimated that around 2 billion people consume alcohol, and approximately 76.3 million have problems associated to its use. ${ }^{2}$ In Brazil, it is difficult to translate the findings of epidemiological studies into intervention strategies due to the country's large territorial extensions with marked social, economic and cultural diversity.

Alcoholic beverages are often an important part of social events as it is socially and legally accepted and even highly valued in some cultures. Adolescence is regarded as a phase of life characterized by physical and psychological changes and a series of discoveries in the search for greater social autonomy. ${ }^{3}$ These factors may contribute to greater vulnerability during adolescence, including engaging in alcohol abuse. ${ }^{4}$ There is a concern of heavy/frequent alcohol use among adolescents with an impact on family and social relationships and morbidity and mortality associated with violence and external causes. ${ }^{5,6}$

Epidemiology has a key role in describing alcohol use among adolescents and there are many related studies with various methodologies, notably those conducted in major cities of southern and southeastern Brazil. ${ }^{7,8,9,10,11,12,13}$ Among the epidemiological surveys involving adolescent students in Brazil it is remarkable a multicenter series carried out by the Brazilian Psychoactive Drug Information Center (CEBRID) in several Brazilian capitals between 1997 and 2004. Alcohol was reportedly the most consumed PD and its use is initiated at the youngest age (about 12 years old). A recent study reported frequent alcohol use among $11.7 \%$ of the students studied and heavy use among $6.7 \% .^{14,12}$

Among factors associated with alcohol 
use among students are notably those associated to family and social environment: separation of parents, conflicts with the mother, permissive parent, being abused, not following a religion, and having a family member who is a drug user. ${ }^{15}$ In contrast, Galduróz et al. ${ }^{12}$ reported in the Fifth National Survey that having a good relationship with one's parents and peer students is a protective factor for heavy alcohol use among adolescents in Northeast Brazil.

Studies that investigate the association between consequences of alcohol use/ abuse and low risk perception are equally relevant as described in events of violence, traffic accidents, unprotected sex, and poor school performance among others. These studies have contributed with more input to bring together different realities allowing the development of more adequate strategies for health promotion.

The objective of the present study was to assess associations between personal, family and social environmental factors and heavy/frequent alcohol use among adolescents attending public schools so that to provide input to the formulation of health policies and actions targeting this young population in the city and semi-arid region of Bahia.

\section{Methods}

Cross-sectional study investigating factors associated with heavy/frequent alcohol use among adolescents in public schools in the city of Feira de Santana. Feira de Santana is the second largest city in the state of Bahia with an estimated population of 571,997 inhabitants, of which 66,085 are adolescents. ${ }^{16}$ In this area there is the largest highway junction in the North and Northeast region.

Multistage cluster sampling was carried out in high schools of the urban area of the city (32,395 students) including students aged between 14 and 19 years as they are better able to understand and participate in the study. There were selected 10 out of 35 schools: 1 small-, 3 medium-, 4 large-size, and 2 special schools. The number of school classes and students from each school were then calculated. It was assumed a $10 \%$ proportion as reference with a $95 \%$ confidence level ( $\mathrm{z}=2)$ and $2 \%$ accuracy; and $20 \%$ were added for losses and refusals. The initial sample included 1,409 students ensuring proportionality and representativeness of participants. $^{17}$

A pre-tested, confidential, self-administered questionnaire was used for data collection. The instrument was structured in blocks and adapted to address personal information and that related to families and social environment of adolescents. The questionnaire was developed following the World Health Organization (WHO) and the Center for Substance Abuse Treatment and Research (CETAD - Universidade Federal da Bahia) recommendations and based on other validated instruments used in similar studies.

Data collection followed a standard procedure of consecutive stages: preparation of a research manual and local staff training; preparation of schools; information on the study; free choice to participate was ensured; preparation of the collection environment (classrooms) - school desks were lined up and no teacher was in the classroom at the time of collection, researchers refrained from close contact with students and all completed questionnaires were returned in a drop-in box that was sealed and coded ensure anonymity ${ }^{18}-$, preparation of a manual for data entry and validation of the database.

Only those students who reported alcohol experimentation/use were analyzed in the study, totaling 776 adolescents. Exposed students were those who reported heavy/ frequent alcohol use and non-exposed were those who reported experimentation/use less than every weekend. The WHO (1981) defines frequent use as alcohol consumption equal to or greater than six times during the 30 days preceding the study and heavy use as alcohol consumption equal to or greater than 20 times during the previous 30 days. In this study, for the purpose of equivalence, heavy/frequent users were 
those who reported alcohol use at least every weekend. ${ }^{19}$

We calculated the prevalence $(\mathrm{P})$ and prevalence ratio $(\mathrm{PR})$ to assess potential associations between the main variable heavy/frequent consumption and covariables (personal information, characteristics of experimentation/use, family, interpersonal and social environmental factors), assuming an error of 0.05 and $95 \%$ confidence interval for statistically significant associations. The study database was created using SPSS 9.0 for Windows.

The present study is part of the Comprehensive Health and Risk Prevention for Adolescents and Youth Project and was approved by the Research Ethics Committee of Universidade Estadual de Feira de Santana (UEFS) (Protocol No. 006/2002) according to Resolution 196/96 of the Brazilian National Health Council. ${ }^{20}$

\section{Results}

The study sample consisted of 766 students aged 14 to 19 years attending state public schools in Feira de Santana. The prevalence of alcohol use was $53.5 \%$ among those who reported use equal to or less than once a month; $29 \%$ from 1 to 3 times a month; $13.1 \%$ frequent use; and $4.4 \%$ more than during weekends (Table 1).

Most adolescents were 17 to 19 years (66.2\%), females (58\%), and were attending the first year of high school (43.7 \%). They mostly lived with their parents $(56.1 \%)$ and were provided by them (65.5\%). Of all adolescents participating in the study, $90.2 \%$ claimed to have good knowledge on PDs and the media was their main source of information (88.2\%) (Table 1).

Table 2 shows that frequent/heavy alcohol use was significantly associated with personal, and family covariables and consumption characteristics: age 17 to 19 years (PR 1.20, 95\% CI 1,08-1.34); male (PR 1.30, 95\% CI 1.08-1.57); early initiation of alcohol use (PR 1.32; PR 1.06-1.66); influence on sex performance (PR 2.12, 95\% CI 1.44-3.13); casual sex partner (PR 1.61, 95\% CI 1.03-2.51); alcohol users in the family (PR 1.70, 95\% CI 1.33-2.17); other PD users in the family (PR 2.51, 95\% CI 1.47-4.3); low maternal schooling (PR 1.50, 95\% CI 1.09-2.05); and living with a partner (PR 4.71, 95\% CI 1.68-13.20).

Frequent/heavy alcohol use showed a positive (significant) association with some motivations and consequences of use (Table 2): pleasure (PR 1.86, 95\% CI 1.22-2.85); amusement (PR 1.53 95\% CI 1.15-2.03); anxiety (PR 2.19, 95\% CI 1.18-4.07); to get drunk (PR 2.02, 95\% CI 1.62-2.51); aggressive behavior (PR 3.94, 95\% CI 2.28-6.81); missing school/work (PR 8.61, 95\% CI 3.25-22.82) and use of other PDs (PR 3.61, 95\% CI 1.62-8.04).

Table 3 shows there was found a positive (significant) association between environmental factors and heavy/frequent alcohol use such as personal income (PR 1.26, 95\% CI 1.04-1.53); drug trafficking in the area (PR 1.36, 95\% CI 1.11-1.66); drinking at their friends' home (PR 1.72, 95\% CI 1.29-2.28) and nearby school (PR 4.17, 95\% CI 2.148.11) and in bars, discos and nightclubs (PR $2.06,95 \%$ CI 1.64-2.58). It is worth noting the low impact of prevention activities carried out at school (PR 3.63, 95\% CI 1.64-8.01).

\section{Discussion}

Studies on substance use often have to address technical-operational issues involving limitations of analysis and potential prevalence bias ${ }^{21}$ as well as issues related to reliability of self-administered questionnaires. This study questionnaire collects self-reported information that is used for assessing exposure, which may be influenced by feelings of embarrassment, attitudes such as lack of attention/seriousness, concerns about confidentiality - all factors that may compromise the respondents' answers and, consequently, the study results. ${ }^{9,10,22,4}$ Thus, data collection in this study followed a careful procedure to control for ethical and sensitive issues, according to recommendations of a reference center specialized PD user care.

The literature shows, based on reports of 
Tabela 1 - Características sócio-demográficas, familiares e sócio-ambientais dos adolescentes usuários de bebidas alcoólicas, Escolas Públicas Estaduais e Urbanas, Feira de Santana, Bahia, 2004.

Table 1 - Sociodemographic, social environmental and family characteristics of adolescent users of alcohol, public urban schools, city of Feira de Santana, northeastern Brazil, 2004.

\begin{tabular}{|c|c|c|}
\hline Sociodemographic, social environmental and family characteristics & $\mathrm{N}$ & $\%$ \\
\hline \multicolumn{3}{|l|}{ Age $^{*}(\mathrm{~N}=760)$} \\
\hline $14-16$ years old & 257 & 33,8 \\
\hline $17-19$ years old & 503 & 66,2 \\
\hline \multicolumn{3}{|l|}{ Gender* $(N=767)$} \\
\hline Female & 445 & 58,0 \\
\hline Male & 322 & 42,0 \\
\hline \multicolumn{3}{|l|}{ School grade * $(N=766)$} \\
\hline grade 9 & 334 & 43,6 \\
\hline grade 10 & 239 & 31,2 \\
\hline grade 11 & 190 & 24,8 \\
\hline accelerated learning program & 3 & 0,4 \\
\hline \multicolumn{3}{|l|}{ Personal income* $(N=769)$} \\
\hline Get money from parents & 504 & 65,5 \\
\hline Work & 319 & 41,5 \\
\hline Get money from relatives & 53 & 6,9 \\
\hline Other & 30 & 3,9 \\
\hline Get money from other people & 19 & 2,5 \\
\hline \multicolumn{3}{|l|}{ Current living arrangements* $(N=768)$} \\
\hline Both parents & 431 & 56,1 \\
\hline Mother & 197 & 25,7 \\
\hline Other1 & 132 & 17,2 \\
\hline Father & 32 & 4,2 \\
\hline Partner & 14 & 1,8 \\
\hline \multicolumn{3}{|l|}{ Occupation status of parents or guardians $* 2(\mathrm{~N}=749)$} \\
\hline Employed & 624 & 82,3 \\
\hline Retired & 155 & 20,7 \\
\hline Unemployed & 120 & 16,0 \\
\hline Income from other sources & 19 & 2,5 \\
\hline \multicolumn{3}{|l|}{ Good knowledge on drugs $(\mathrm{N}=747$ ) } \\
\hline Yes & 674 & 90,2 \\
\hline \multicolumn{3}{|l|}{ Source of information on psychoactive drugs ( $N=774)$} \\
\hline Media & 683 & 88,2 \\
\hline School/seminars/talks & 483 & 62,4 \\
\hline Family & 397 & 51,3 \\
\hline Friends & 381 & 49,2 \\
\hline Church & 188 & 24,3 \\
\hline Other ${ }^{3}$ & 36 & 4,7 \\
\hline \multicolumn{3}{|l|}{ School activities on psychoactive drugs ( $N=757$ ) } \\
\hline Yes & 571 & 75,4 \\
\hline \multicolumn{3}{|l|}{ Alcohol use $(\mathrm{N}=776)$} \\
\hline Less than once a month & 415 & 53,5 \\
\hline 1 to 3 times a month & 225 & 29,0 \\
\hline Frequent use (every weekend) & 102 & 13,1 \\
\hline More than on every weekend & 34 & 4,4 \\
\hline
\end{tabular}


Tabela 2 - Razão de prevalência do consumo de bebidas alcoólicas, segundo covariáveis pessoais, familiares e características de iniciação, Escolas Públicas Estaduais e Urbanas, Feira de Santana, Bahia, 2004.

Table 2 - Prevalence of the consumption of alcoholic beverages according to personal and family co-variables and characteristics of initiation, Public and Urban Schools, Feira de Santana, Bahia, 2004.

\begin{tabular}{|c|c|c|c|c|c|c|}
\hline \multirow{3}{*}{$\begin{array}{l}\text { Personal and family co-variables and initiation } \\
\text { characteristics }\end{array}$} & \multicolumn{6}{|c|}{ Alcohol use } \\
\hline & \multicolumn{2}{|c|}{ Heavy/frequent use } & \multicolumn{2}{|c|}{$\leq 3$ times a month } & \multirow[t]{2}{*}{ PR } & \multirow[t]{2}{*}{$95 \% \mathrm{Cl}$} \\
\hline & $n$ & $\%$ & $\mathrm{~N}$ & $\%$ & & \\
\hline \multicolumn{7}{|l|}{ Age } \\
\hline 14-16 years old & 31 & 23,1 & 226 & 36,1 & 0,64 & $0,46-0,89^{*}$ \\
\hline 17-19 years old & 103 & 76,9 & 400 & 63,9 & 1,20 & $1,08-1,34^{*}$ \\
\hline \multicolumn{7}{|l|}{ Gender } \\
\hline Male & 70 & 51,9 & 252 & 39,9 & 1,30 & $1,08-1,57^{*}$ \\
\hline Female & 65 & 48,1 & 380 & 60,1 & 0,93 & $0,77-1,12$ \\
\hline \multicolumn{7}{|l|}{ Age at initiation } \\
\hline$\leq 13$ years old & 52 & 47,3 & 197 & 35,7 & 1,32 & $1,06-1,66^{*}$ \\
\hline $14-15$ years old & 45 & 40,9 & 244 & 44,2 & 0,93 & $0,73-1,18$ \\
\hline $16-17$ years old & 8 & 7,3 & 100 & 18,1 & 0,40 & $0,20-0,80^{*}$ \\
\hline 18 years old & 5 & 4,5 & 11 & 2,0 & 2,28 & $0,81-6,44$ \\
\hline \multicolumn{7}{|l|}{ Interference of alcohol use with sex } \\
\hline Yes & 29 & 24,4 & 68 & 11,5 & 2,12 & $1,44-3,13^{*}$ \\
\hline \multicolumn{7}{|c|}{ Characterization of interference of alcohol use with sex } \\
\hline Casual sex & 15 & 60,0 & 25 & 37,3 & 1,61 & $1,03-2,51^{*}$ \\
\hline No condom use & 7 & 28,0 & 12 & 17,9 & 1,56 & $0,69-3,52$ \\
\hline Difficult to put condoms on & 4 & 16,0 & 11 & 16,4 & 0,97 & $0,34-2,78$ \\
\hline Sex in exchange for money or drugs & 1 & 4,0 & 5 & 7,5 & 0,54 & $0,07-4,37$ \\
\hline \multicolumn{7}{|l|}{ Alcohol abuser in the family } \\
\hline Yes & 55 & 42,3 & 154 & 24,9 & 1,70 & $1,33-2,17^{*}$ \\
\hline \multicolumn{7}{|l|}{ Users of other PDs in the family } \\
\hline Yes & 18 & 14,0 & 34 & 5,6 & 2,51 & $1,47-4,30^{*}$ \\
\hline \multicolumn{7}{|l|}{ Current living arrangements* $(\mathrm{N}=768)$} \\
\hline Both parents & 78 & 58,2 & 353 & 55,7 & 1,05 & $0,89-1,23$ \\
\hline Mother & 33 & 24,6 & 164 & 25,9 & 0,95 & $0,69-1,32$ \\
\hline Other* & 18 & 13,4 & 114 & 18,0 & 0,75 & $0,47-1,18$ \\
\hline Partner & 7 & 5,2 & 7 & 1,1 & 4,73 & $1,69-13,27^{*}$ \\
\hline Father & 3 & 2,2 & 29 & 4,6 & 0,49 & $0,15-1,58$ \\
\hline \multicolumn{7}{|l|}{ Mother's schooling } \\
\hline Yes & 66 & 64,7 & 372 & 74,8 & 0,86 & $0,74-1,01$ \\
\hline No & 35 & 34,3 & 114 & 22,9 & 1,50 & $1,09-2,05^{*}$ \\
\hline Do not know & 1 & 1,0 & 11 & 2,0 & 0,44 & $0,06-3,39$ \\
\hline \multicolumn{7}{|l|}{ Motivations for alcohol use } \\
\hline Out of curiosity & 42 & 34,7 & 277 & 48,8 & 0,77 & $0,59-0,99 *$ \\
\hline Pleasure & 24 & 19,8 & 65 & 11,4 & 1,86 & $1,22-2,85^{*}$ \\
\hline Shyness & 18 & 14,9 & 105 & 18,5 & 0,87 & $0,55-1,37$ \\
\hline Amusement & 42 & 34,7 & 139 & 24,5 & 1,53 & $1,15-2,03^{*}$ \\
\hline Anxiety & 13 & 10,7 & 30 & 5,3 & 2,19 & $1,18-4,07^{*}$ \\
\hline Peer acceptance & 4 & 3,3 & 18 & 3,2 & 1,12 & $0,39-3,26$ \\
\hline Other & 13 & 10,7 & 79 & 13,9 & 0,83 & $0,48-1,44$ \\
\hline \multicolumn{7}{|l|}{ Behavior after experimentation } \\
\hline None & 50 & 41,7 & 399 & 65,8 & 0,59 & $0,47-0,73^{*}$ \\
\hline ot drunk & 64 & 53,3 & 149 & 24,6 & 2,02 & $1,62-2,51^{*}$ \\
\hline Aggressive behavior & 21 & 17,5 & 25 & 4,1 & 3,94 & $2,28-6,81^{*}$ \\
\hline Injured/caused accidents & 3 & 2,5 & 3 & 0,5 & 4,69 & $0,96-22,98$ \\
\hline Missed school/work & 11 & 9,2 & 6 & 1,0 & 8,61 & $3,25-22,82^{*}$ \\
\hline Used another type of PDs & 10 & 8,3 & 13 & 2,1 & 3,61 & $1,62-8,04^{*}$ \\
\hline Other & 7 & 5,8 & 21 & 3,5 & 1,56 & $0,68-3,60$ \\
\hline
\end{tabular}

"Alone, other relatives and other people. 
Tabela 3 - Razão de prevalência do consumo de bebidas alcoólicas, segundo covariáveis socioambientais, Escolas Públicas Estaduais e Urbanas, Feira de Santana, Bahia, 2004.

Table 3 - Prevalence of the consumption of alcoholic beverages according to socio-environmental co-variables, Public and Urban Schools, Feira de Santana, Bahia, 2004.

Social environmental factors

\begin{tabular}{|c|c|c|c|}
\hline \multicolumn{4}{|c|}{ Social environmental factors } \\
\hline Heavy/frequent use & $\leq 3$ times a month & $P R$ & IC (95\%) \\
\hline$\%$ & $\%$ & & \\
\hline
\end{tabular}

\section{Personal income}

Get money from parents

Work

$\begin{array}{cccccc}72 & 53,7 & 432 & 68,0 & 0,79 & 0,67-0,93^{*} \\ 67 & 50,0 & 252 & 39,7 & 1,26 & 1,04-1,53^{*} \\ 10 & 7,5 & 43 & 6,8 & 1,10 & 0,57-2,14 \\ 6 & 4,5 & 13 & 2,0 & 2,19 & 0,85-5,65 \\ 6 & 4,5 & 24 & 3,8 & 1,18 & 0,49-2,84\end{array}$

Violence in the neighborhood

Thefts/robberies

$\begin{array}{cccccc}106 & 80,9 & 474 & 74,8 & 1,08 & 0,98-1,19 \\ 60 & 45,8 & 265 & 41,8 & 1,10 & 0,89-1,35 \\ 44 & 33,6 & 185 & 29,2 & 1,15 & 0,88-1,51 \\ 65 & 49,6 & 231 & 36,4 & 1,36 & 1,11-1,66^{*} \\ 2 & 3,8 & 15 & 4,7 & 0,65 & 0,15-2,79\end{array}$

\section{Place of alcohol use}

Home

Home of friends

Nearby school

Bars, discos and nightclubs

Parties

Other $^{3}$

\section{Educational activities performed at school}

Yes

\begin{tabular}{cccccc}
44 & 36,7 & 163 & 28,7 & 1,28 & $0,98-1,67$ \\
44 & 36,7 & 121 & 21,3 & 1,72 & $1,29-2,28^{*}$ \\
15 & 12,5 & 17 & 3,0 & 4,17 & $2,14-8,11^{*}$ \\
61 & 50,8 & 140 & 24,7 & 2,06 & $1,64-2,58^{*}$ \\
83 & 69,2 & 409 & 72,1 & 0,96 & $0,84-1,09$ \\
4 & 3,3 & 18 & 3,2 & 1,05 & $0,36-3,05$ \\
& & & & & \\
105 & 80,8 & 466 & 74,3 & 1,09 & $0,99-1,20$ \\
& & & & & \\
54 & 61,4 & 260 & 62,7 & 0,98 & $0,82-1,17$ \\
24 & 27,3 & 142 & 34,2 & 0,80 & $0,55-1,15$ \\
10 & 11,4 & 13 & 3,1 & 3,63 & $1,64-8,01^{*}$ \\
\hline
\end{tabular}

Educational activities at school

Adds a lot to their knowledge

Adds little to their knowledge

Adds nothing to their knowledge

${ }^{1}$ Gets Money from boyfriend, husband works sometimes.

${ }^{2}$ Kidnapping, beating, fights.

${ }^{3}$ Concerts, shopping mall, home of relatives.

other researchers in this field of knowledge, that the most widely used approach for indicators and prevalence studies including young people are self-administered questionnaires applied in schools. ${ }^{23,11}$ When consistently applied, this approach ensures the collection of reliable information. ${ }^{24}$

Adolescence is a life phase characterized by physical, psychological and social changes, ${ }^{25,26}$ but most importantly it is a time of transition from the family into a broader social environment when adolescents push the limits and question the standards ${ }^{27}$ seeking to strengthen their behaviors. ${ }^{28}$ This process involve greater exposure to multiple risks that can affect the basic skills required to their social inclusion. ${ }^{29}$

With respect to PD use, it is known that alcohol is socially accepted since the Ancient Age. ${ }^{5}$ Alcohol has been identified as 
the most commonly consumed substance among adolescents ${ }^{1,15,6,30,4}$ and alcohol abuse has grown in recent decades. ${ }^{23}$ There is a growing concern about alcohol use patterns and related behaviors in adolescents based on indicators of social, economic and health impact. ${ }^{19,32,33}$

Alcohol use by adolescents can be associated to a number of implications, especially greater peer acceptance, increased alcohol use, low-risk perception, greater risk of injuries, violence, sexually transmitted diseases, among others. ${ }^{34}$

In Brazil, the prevalence of alcohol experimentation and use among adolescents varies depending on the context studied. In Feira de Santana, the prevalence of use "less than once a month" was $20.7 \%$ in younger (14-16 years old) and 33\% for older adolescents (17-19 years old), which is lower than that reported for "lifetime use and use in a year" in other recent studies with Brazilian students living in medium-size and large cities. ${ }^{23,8,9,10,35,12,36,13}$

As for heavy/frequent use, the study findings were consistent with those reported in the city of Pelotas (5\% and $16.8 \%$, respectively) and São José do Rio Preto (1.4\% and $15.1 \%)^{9}$ and corroborate the findings of Galduróz et al. ${ }^{12}$ in a study conducted with adolescents in schools in 27 Brazilian cities (6.7\% and $11.7 \%)$.

Adolescents reported good knowledge on PDs and they had access to information especially in the media (television, radio, magazines and newspapers). It evidences the media influence and involvement in determining youth behaviors, suggesting the need for actions promoting rational and educational media use and increased regulation of alcohol advertising.

Some authors point to the influence of social environments for an increased prevalence of alcohol use, highlighting the importance of taking into consideration sociodemographic factors in the planning of policies and prevention programs. ${ }^{9,37,23}$

The literature shows different patterns of alcohol use by gender and age. ${ }^{1}$ In the present study, there was found a signifi- cant association between late adolescence (17-19) and heavy/frequent alcohol use with rates proportional to age; older adolescents reported 1.20 times higher consumption than younger ones. These results corroborate similar studies conducted in schools in large Brazilian cities. ${ }^{7,9,10,36} \mathrm{Heavy} /$ frequent alcohol use was also significantly more prevalent among males, and the measure of association (PR) was 1.3. Similar stu-

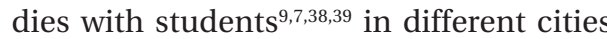
in South and Southeast Brazil also found the same association. Similar results were reported by Horta, Horta and Pinheiro ${ }^{40}$ in a household survey with adolescents in the city of Pelotas.

The present study also found a positive association between heavy/frequent use and early experimentation (younger than 13). These findings corroborate other studies conducted with public and private school students, such as that carried out in the city of Paulínia, Southeastern Brazil, that found a significant association between early initiation of alcohol use, more episodes of alcohol intoxication, and use of tobacco and other PDs. ${ }^{13}$

Despite sale of alcohol to adolescents are prohibited according to the Brazilian Statute for Children and Adolescents, ${ }^{41}$ in Brazil young people experiment alcohol at early ages, which affects their pattern of use and exposure to risk factors and have an impact on morbidity and mortality rates from external causes and injuries. ${ }^{42}$

Injuries are the second leading cause of death among Brazilian adolescents, following homicides, with greater impact on males. ${ }^{42,43,44}$ Alcohol use is the main cause of injuries and the Institute of Applied Economic Research (IPEA) estimated an economic impact of about $\mathrm{R} \$ 24$ billion in $2006 .^{43}$

Personal income also was positively associated with heavy/frequent alcohol use among adolescents in Feira de Santana, which corroborates the findings of Galduróz et al., ${ }^{12}$ Souza, Areco and Silveira Filho ${ }^{45}$ and Souza and Silveira Filho. ${ }^{35}$ A study conducted in Campinas, southeastern Brazil, found a risk of heavy alcohol use 2.2 times higher 
among working adolescents.

The authors studying the relationship between work and PD use argue that stress may be a potential factor explaining this association due to working conditions and consequent early work commitment with socialization patterns linked to work, adult world and economic independence. ${ }^{46,47}$ These arguments contrast with the social acceptance of work and the notion that reducing leisure time may represent a protective factor for heavy/frequent use of PDs.

Carvalho and Carlini-Cotrim ${ }^{47}$ explained that the association between PD use and leisure time follows a prevention model, known for offering alternatives. These authors investigated more than 16,000 school adolescents in 15 Brazilian cities and concluded that alcohol prevention programs developed to merely, often involuntarily, involve people in leisure-time activities have actually little effect. And rather than just keeping adolescents busy these programs should be an opportunity for them to develop their potentialities.

An interesting finding of the original study on which the present study was based ${ }^{30}$ concerns the association between alcohol use and vulnerability and risk factors, illustrated by the finding of a positive association between alcohol use and casual sex. Epidemiological studies focusing on adolescence also reported similar findings, pointing to the relationship between sexual risk behavior and PD use. ${ }^{8,48,49}$ There is a consensus in the literature regarding the association between early sexual initiation and use of PDs, suggesting a need for integrated prevention actions for STD/AIDS and PD use.

Pechansky et al. ${ }^{15}$ stress among factors associated with alcohol use in students those related to the family structure such as separation of parents, parental conflicts, excessive permissiveness, abuse, no religious practice, and drug users in the family. Some studies points to the importance of taking into consideration the family and social and cultural environments in the implementation of policies and prevention and intervention programs with the involvement of different actors that influence behaviors and lifestyle habits among young.

With regard to family factors, adolescent health programs have to consider family structure, living environment and housing conditions. Some authors underline the importance of the family as either a risk or protective factor for alcohol abuse, dependent on trust relationship, communication between members, and parent behavior model. $^{32,50,51,52,53}$

Studies on use of PDs among adolescents that investigated family habits have concluded that certain patterns of family structure and habits seem to play a role in the development of behaviors. ${ }^{54} \mathrm{~A}$ study carried out in a reference center for PD dependent adolescents in Rio de Janeiro showed that the prevalence of PD use in families of adolescent users was four times higher than that seen in population-based studies in Brazil. ${ }^{55}$

There is a consensus that PD use in the family seems to have a negative effect as it interferes in a conflicting manner with affective bonds, and authority, and may result in excessive permissiveness, and poor monitoring, among others. In contrast, healthy family relationships act as protective factors in setting standards for social behaviors such as use of PDs. However, based on their experience, some authors ${ }^{52}$ point out that alcohol abuse by parents and their children is not a one-dimensional relationship.

The present study also found that low maternal schooling was more prevalent among adolescents reporting heavy/ frequent alcohol use. Souza, Areco and Silveira Filho ${ }^{45}$, in a study conducted with adolescents from state schools in Cuiabá, central-western Brazil, reported a positive association between recent alcohol use and low schooling of family head. These results seem to indicate greater role of the mother in child rearing as more than $25 \%$ of adolescents said they lived with one parent (mother) only.

Of the environmental factors studied, frequent/heavy alcohol use was associated with living with a partner, area of residen- 
ce, drug trafficking in the neighborhood, drinking at their friends' home, in bars and nearby school. According to Schenker and Minayo, ${ }^{50}$ the family is a prime locus for primary socialization and although adolescents are expected to focus their attention on their peers, outside the family, to understand them it is crucial to examine their integration into the environment family where they learn how to socially interact. A study conducted with adolescents in a university health service (RJ) found that living with both parents was a protective factor for PD use ${ }^{55}$

Having good knowledge on PDs is supposedly a protective factor for frequent/ heavy alcohol use. However, in this study, we can infer that PD prevention activities carried out at school did not contribute much to the students' understanding, showing a positive association with frequent/ heavy alcohol use. This finding points out to a need for reviewing the strategies currently used and actions should be implemented with realistic expectations and based on the adolescent's demands and needs.

In conclusion, epidemiological studies on alcohol abuse provide input to support the implementation of policies and prevention actions as well as educational programs targeting adolescents, families and schools.

\section{Conclusions}

1. Male adolescents aged 17 to 19 years who had an early initiation of alcohol use (before the age of 13) had the highest prevalence of heavy/frequent alcohol use;

2. The main reasons for heavy/frequent alcohol use was pleasure, amusement and anxiety;

3. Alcohol and other PD use in the family, low maternal schooling, living with a partner and having a paid job were some of the main personal and family factors associated to frequent/ heavy alcohol use;

4. Environmental factors associated with heavy/frequent alcohol use included drinking with friends and drug trafficking in the neighborhood;

5. The consequences of heavy/frequent alcohol use included casual sex, aggressive behaviors, absenteeism and use of other PDs.

\section{Final comments}

Prevalence studies, despite limitations of analysis, can provide valuable input for planning, prevention and injury reduction strategies. To address the issue of excessive intake of alcohol requires both strengthening of policies and programs that promote social awareness and control of supply and access to alcohol as well as awareness in the family environment on the potential protective and risk factors involving parental habits.

\section{References}

1. MELONI J.N., LARANJEIRA R. Custo social e de saúde do consumo de álcool. Rev Bras Psiquiatr 2004, 26(S1): 7-10.

2. WORLD HEALTH ORGANIZATION. Global Status Report on Alcohol. Geneva, 2004.

3. COSTA MCO, GOMES WA. Crescimento e desenvolvimento na infância e adolescência. In: COSTA MCO, SOUZA RP. Semiologia e atenção primária à criança e ao adolescente. 2ed. Rio de Janeiro: Revinter; 2005. p. 17-60.
4. VIEIRA DL, RIBEIRO M, ROMANO M, LARANJEIRA R. Álcool e adolescentes: estudo para implementar políticas municipais. Rev Saúde Pública 2007; 41(3): 396 403.

5. GIGLIOTTI A, BESSA MA. Síndrome de dependência do álcool: critérios diagnósticos. Rev Bras Psiquiatr 2004; 26(S1): 11-13.

6. SCIVOLETTO, S. Abuso e dependência de drogas na adolescência. In: ASSUMPÇÃO JUNIOR F, KUCZYNSKI E. Adolescência Normal e patológica. São Paulo: Lemos Editorial, 1999. P.125-48. 
7. CARLINI BH, PIRES MLN, FERNANDES R, MASUR, J. Alcohol use among adolescentes in São Paulo, Brazil. Drug and alcohol dependence 1986; 18: 235-46.

8. SCIVOLETTO S, TSUJI RK, ABDO CHN, QUEIRÓZ S, ANDRADE AG, GATAZZ WF. Relação entre consumo de drogas e comportamento sexual de estudantes de $2^{\circ}$ grau de São Paulo. Rev Bras Psiquiatr 1999, 21(2): 87-94.

9. TAVARES BF, BÉRIA JU, LIMA MS. Prevalência do uso de drogas e desempenho escolar entre adolescentes. Rev Saúde Pública 2001; 35(2): 150-8.

10. BAUS J, KUPEK E, PIRES M. Prevalência e fatores de risco relacionados ao uso de drogas entre escolares. Rev Saúde Pública 2002; 36(1): 40-6.

11. SOLDERA MA, DALGALARRONDO P, CORREA FILHO HR, SILVA CAM. Uso de drogas psicotrópicas por estudantes: prevalência e fatores associados. Rev. Saúde Pública 2004; 38(2): 277-83.

12. GALDURÓZ JC, NOTO AR, FONSECA AM, CARLINI EA. V Levantamento Nacional sobre o consumo de drogas psicotrópicas entre estudantes de ensino fundamental e médio da rede pública de ensino nas 27 capitais brasileiras. São Paulo: CEBRID - Centro Brasileiro de Informações sobre Drogas psicotrópicas; UNIFESP Universidade Federal de São Paulo, 2004.

13. VIEIRA DL, RIBEIRO M, LARANJEIRA R. Evidence of association between early alcohol use and risk of later problems. Rev Bras Psiquiatr 2007; 29(3): 222-7.

14. GALDURÓZ JC, NOTO AR, CARLINI EA. IV Levantamento sobre o uso de drogas entre estudantes do $1^{\circ}$ e $2^{\circ}$ graus em dez capitais brasileiras. São Paulo: CEBRID - Centro Brasileiro de Informações sobre Drogas psicotrópicas; UNIFESP - Universidade Federal de São Paulo, 1997. P. 400.

15. PECHANSKY FS, SZOBOT CM, SCIVOLETTO S. Uso de álcool entre adolescentes: conceitos, características epidemiológicas e fatores etiopatogênicos. Rev Bras Psiquiatr 2004: 26(S1): 14-7.

16. Instituto Brasileiro de Geografia e Estatística. Contagem populacional. Informações estatísticas de Feira de Santana. Brasília, 2008.

17. FONSECA JS, MARTINS GA. Curso de estatística. 3 ed. São Paulo: Atlas; 1987. P.

18. ALVES MVQM. Consumo de álcool, tabaco e outras substâncias psicoativas entre adolescentes de Feira de Santana, Bahia. [dissertação de mestrado]. Feira de Santana: Universidade Estadual de Feira de Santana, 2004.

19. WORLD HEALTH ORGANIZATION. Nomenclature and classification of drug and alcohol related problems: a WHO memorandum. Bull World Health Organ 1981; 59: 225-45.

20. BRASIL. Conselho Nacional de Saúde. Resolução no 196 , Diretrizes e Normas Regulamentadoras de Pesquisas Envolvendo Seres Humanos. 1996.
21. PEREIRA MG. Epidemiologia. Teoria e Prática. Rio de Janeiro: Guanabara Koogan, 1995. P298.

22. COSTA JSD, SILVEIRA MF, GAZALLE FK, OLIVEIRA SS, HALLAL PC, MENEZES AMB et al. Consumo abusivo de álcool e fatores associados: estudo de base populacional. Rev. Saúde Pública 2004, 38(2): 284-91.

23. MUZA GM, BETTIOL H, MUCCILLO G, BARBIERI MA. Consumo de substâncias psicoativas por adolescentes escolares de Ribeirão Preto, SP (Brasil). I Prevalência do consumo por sexo, idade e tipo de substância. Rev Saúde Pública 1997; 31(1): 21-9.

24. COSTA MCO, ALVES MVQM, SANTOS CAST, CARVALHO RC, SOUZA KEP, SOUSA HL. Experimentação e uso regular de bebidas alcoólicas, cigarros e outras substâncias psicotivas/SPA na adolescência. Ciênc Saúde Coletiva 2007; 12(5): 1143-54.

25. MUUSS, RE. Theories of adolescence. 5 ed. Belo Horizonte: Interlivros, 1976. P. 426.

26. ASSUMPÇÃO JUNIOR FB, KUCZYNSKI E. Adolescência normal e patológica. São Paulo: Lemos Editorial; 1999. P. 239.

27. TOMMASI MCF. Desenvolvimento emocional e cognitivo do adolescente. In: ASSUMPÇÃO JÚNIOR FB, KUCZYNSKI E. Adolescência normal e patológica. São Paulo: Lemos Editorial, 1999. P.33-47.

28. REBOLLEDO EAO, MEDINA NMO, PILLON SC. Factores de riesgo asociados al uso de drogas en estudiantes adolescentes. Rev Latino-am de Enfermagem 2004; 12 : 369-75.

29. ORGANIZAÇÃO PANAMERICANA DE SAÚDE (OPAS). Saúde integral do adolescente e do jovem. Brasília, 2007.

30. ALVES MVQM, COSTA MCO, NASCIMENTO SOBRINHO CL, SANTOS CAST, GOMES WA, ASSIS DR. Uso de bebidas alcoólicas entre adolescentes: perfil de experimentação, uso regular e fatores de risco. Feira de Santana, Bahia. Rev Baiana Saúde Pública 2005; 29(1): 91-104.

31. LUCAS ACS, PARENTE RCP, PICANÇO NS. Uso de psicotrópicos entre universitários da área da saúde da Universidade Federal do Amazonas, Brasil. Cad Saúde Pública 2006, 22(3): 663-71.

32. CARLINI EA, GALDURÓZ JCF, NOTOA AR, NAPPO SA. I Levantamento domiciliar sobre o uso de drogas no Brasil. São Paulo: CEBRID - Centro Brasileiro de Informações sobre Drogas psicotrópicas; UNIFESP Universidade Federal de São Paulo, 2002.

33. SUDBRACK MFO, CESTARI DM. O modelo sistêmico e da educação para a saúde na prevenção da drogadição no contexto da escola: proposta do Projeto Piloto SENAD/MEC e UNB. In: Anais do $1^{\circ}$ Simpósio Internacional do Adolescente, 2005 - Adolescência hoje: desafios, práticas e políticas, Fac Educação USP, São Paulo, 2005. 
34. LEMOS T, ZALESKI M. As principais drogas: como elas agem e quais os seus efeitos. In: PINSKY I, BESSA MA. Adolescência e drogas. São Paulo: Contexto, 2004.

35. GUIMARÃES JL, GODINHO PH, CRUZ R, KAPPANN JI, TOSTA JUNIOR LA. Consumo de drogas psicoativas por adolescentes escolares de Assis, SP. Rev Saúde Pública 2004; 38(1): 130-2.

36. SOUZA DPO, SILVEIRA FILHO DX. Uso recente de álcool, tabaco e outras drogas entre adolescentes trabalhadores e não trabalhadores. Rev Bras Epidemiol 2007; 10(2): 276-87.

37. TAVARES BF, BÉRIA JU, LIMA MS. Fatores associados ao uso de drogas entre adolescentes escolares. Rev Saúde Pública 2004, 38(6): 787-96.

38. TROIS CC, FRANTZ BC, YALUK JB, TARONCHER CA, SCHNEIDER W, SCHONELL LHB, et al. Prevalência de CAGE positivo entre estudantes de segundo grau de Porto Alegre, Rio Grande do Sul, Brasil, 1994. Cad Saúde Pública 1997; 13(3): 489-95.

39. SILVA EF, PAVANI RAB, MORAES MS, CHIARAVALLOTI NETO, F. Prevalência do uso de drogas entre escolares do ensino médio do Município de São José do Rio Preto, São Paulo, Brasil. Cad Saúde Pública 2006; 22(6): 1151-8.

40. HORTA RL, HORTA BL, PINHEIRO RT, MORALES B, STREY MN. Tabaco, álcool e outras drogas entre adolescentes de Pelotas, Rio Grande do Sul: uma perspectiva de gênero. Cad Saúde Pública 2007: 23(4): 775-83.

41. BRASIL. Estatuto da criança e do adolescente. Lei no 8.069, de 13 de julho de 1990. Diário Oficial da União 1990.

42. PINSKY, I; PAVARINO FILHO, R V, 2007 A apologia do consumo de bebidas alcoólicas e da velocidade no trânsito do Brasil: considerações sobre a propaganda de dois problemas de saúde pública. Rev Psiquiatr, 29 (1); 110-118, 2007.

43. BRASIL. Secretaria de Vigilância em Saúde. Boletim Eletrônico n 27, 2007.

44. GAWRYSZEWSKY VP, KOIZUMI MS, MELLO-JORGE MHP. As causas externas no Brasil no ano 2000: comparando a mortalidade e a morbidade. Cad Saúde Pública 2004; 20(4): 995-1003.
45. SOUZA DPO, ARECO KN, SILVEIRA FILHO DX. Álcool e alcoolismo entre adolescentes da rede estadual de ensino de Cuiabá, Mato Grosso. Rev Saúde Pública 2005; 39(4): 585-92.

46. SOLDERA MA, DALGALARRONDO P, CORREA FILHO HR, SILVA CAM. Uso pesado de álcool por estudantes dos ensinos fundamental e médio de escolas centrais e periféricas de Campinas (SP): prevalência e fatores associados. Rev Bras Psiquiatr 2004; 36(3): 174-9.

47. CARVALHO VA; CARLINI-COTRIM, BC. Atividades extra-curriculares e prevenção ao abuso de drogas: uma questão polêmica. Rev Saúde Pública 1992; 26 (3): 145-9.

48. TAQUETTE ST, VILHENA MM, PAULA MC. Doenças sexualmente transmissíveis na adolescência: estudo de fatores de risco. Rev Soc Bras Medicina Tropical 2004; 37(3): $210-4$.

49. TAQUETTE SR, ANDRADE RB, VILHENA MM, PAULA MC. A relação entre as características sociais e comportamentos da adolescente e as doenças sexualmente transmissíveis. Rev Assoc Med Bras 2005; 51(3): 148-52.

50. SCHENKER M, MINAYO MCS. A implicação da família no uso abusivo de drogas: uma revisão crítica. Ciênc Saúde Coletiva 2003, 8(1): 299-306.

51. SCHENKER M, MINAYO MCS. A importância da família no tratamento do uso abusivo de drogas: uma revisão de literatura. Ciênc Saúde Coletiva 2004, 20(3): 649-59.

52. SCHENKER M, MINAYO MCS. Fatores de risco e de proteção para o uso de drogas na adolescência. Ciênc Saúde Coletiva; 10(3): 707-17, 2005.

53. PRATA EMM, SANTOS MA, Adolscência e uso de substâncias psicoativas: o impacto do nível socioeconômico. Rev Latino-am Enfermagem (15) número especial: 806-11, 2007;

54. HORTA RL, HORTA BL, PINHEIRO RT. Drogas: famílias que protegem e que expõem adolescentes ao risco. J Bras Psiquiatr 2006; 55(4): 268-72.

55. SILVA VA, AGUIAR AS, FELIX F, REBELLO GP, ANDRADE RC, MATTOS HF. Brasilian study on substance misuse in adolescents: associated factors and adherence to treatment. Rev Bras Psiquiatr 2003; 25(3): 133-8. 